\title{
Selection of Smart Museums According to Multi-Criteria Decision- Making Technique: AHP Method
}

\author{
Erkan AKGÖZ ${ }^{1}$, Simge ŞALVARCI ${ }^{2}$, F. Kübra AYLAN ${ }^{3}$ \& Hatice SARI GÖK ${ }^{4}$
}

\begin{abstract}
Innovations and developments in information and communication technologies are effective in the emergence of new approaches and innovative business models in tourism as well as in many other fields. Museums, which are among the most popular attractions for tourism destinations, are places that undertake the task of promoting and preserving culture and heritage. The application and use of developments in information and communication technologies in museums will contribute to the increase of interest in these places. In this study, technology applications in museums were discussed, and factors affecting the choice of the smart museum with interactive multi-criteria decision-making methods of application of technology in museums in Turkey has been determined. Alanya Archeology Museum, Çorum Archeology Museum, Ankara Anatolian Civilizations Museum, Burdur Archeology Museum, Antalya Museum, Ankara State Painting and Sculpture Museum, and Zeugma Museum were determined as the study area. The selected museums were evaluated according to the criteria of virtual reality, interactive exhibition, easy access in digital vehicles, and the devices used, and the applications in the museums were examined according to the multi-criteria decision-making method. According to the results of the research, it was determined that many factors affect the smart museum selection, but the most important factor affecting the smart museum selection is virtual reality applications.
\end{abstract}

Key Words: Museum, Smart Museum, Technology Applications in Museums, AHP.

\section{Akıllı Müzelerin Çok Kriterli Karar Verme Tekniğine Göre Seçimi: AHP Yöntemi}

$\ddot{O} z$

Bilgi ve iletişim teknolojilerindeki yenilikler ve gelişmeler birçok alanda olduğu gibi turizm alanında da yeni yaklaşımların ve yenilikçi işletme modellerinin ortaya çıkmasında etkili olmaktadır. Turizm destinasyonları için en popüler çekicilikler arasında yer alan müzeler, kültür ve mirasın tanıtımı ve korunması görevini üstlenen mekânlardır. Bilgi ve iletişim teknolojilerindeki gelişmelerin müzelerde uygulanması ve kullanılması bu mekânlara olan ilginin artmasına katk1 sağlayacaktır. Çalışmada müzelerdeki teknolojik uygulamalar ele alınmış olup Türkiye'deki müzelerde interaktif teknoloji uygulamaları çok kriterli karar verme yöntemiyle akıllı müze seçimini etkileyen faktörler belirlenmeye çalışılmışır. Çalışma alanı olarak, Alanya Arkeoloji Müzesi, Çorum Arkeoloji Müzesi, Ankara Anadolu Medeniyetleri Müzesi, Burdur Arkeoloji Müzesi, Antalya Müzesi, Ankara Devlet Resim ve Heykel Müzesi ve Zeugma Müzesi tespit edilmiştir. Seçilen müzeler sanal gerçeklik, interaktif sergileme, dijital araçlarda kolay ulaşım ve kullanılan cihazlar kriterlerine göre değerlendirilmiş ve müzelerdeki uygulamalar çok kriterli karar verme yöntemine göre incelenmiştir. Araştırma sonuçlarına göre akıllı müze seçimini birçok faktörün etkilediği ancak akıllı müze seçimini etkileyen en önemli faktörün sanal gerçeklik uygulamaları olduğu tespit edilmiştir.

Anabtar Kelimeler: Müze, Akıllı Müze, Müzelerde Teknoloji Uygulamaları, AHP

\section{Atıf İçin / Please Cite As:}

Akgöz, E., Şalvarcı, S., Aylan,F.K. ve Sarı Gök, H. (2021). Selection of Smart Museums According to Multi-Criteria Decision- Making Technique: AHP Method. Manas Sosyal Arasttrmalar Dergisi, 10(3), 2008-2025.

Geliş Tarihi / Received Date: 06.02.2021

Kabul Tarihi / Accepted Date: 16.04.2021

\footnotetext{
${ }^{1}$ Doç. Dr. - Selçuk Üniversitesi Turizm Fakültesi, eakgoz@hotmail.com

iD ORCID: 0000-0001-6723-0271

2 Dr. Öğr. Üyesi - Selçuk Üniversitesi Beyşehir Ali Akkanat Turizm Fakültesi, simgetokay@selcuk.edu.tr.

iD ORCID: 0000-0003-0703-4126

${ }^{3}$ Dr. Öğr. Üyesi - Selçuk Üniversitesi Turizm Fakültesi, kubraceliloglu@gmail.com

(iD) ORCID: 0000-0002-6703-2934

${ }^{4}$ Dr. Öğr. Üyesi - Isparta Uygulamalı Bilimler Üniversitesi Yalvaç Meslek Yüksekokulu, haticesarigok@isparta.edu.tr

iD ORCID: 0000-0003-0949-2593
} 


\section{Introduction}

Museums are the places that promote the societies' lifestyles and cultures, preserve these values and transfer them to future generations. Museums that collect, preserve, interpret and present many works, works and objects that have cultural, artistic, scientific and historical characteristics and are important attractions and areas of tourism. In addition, museums are at the center of the tourism phenomenon as they are among the income-generating institutions of the countries. For this reason, it is the institutions that should be emphasized due to the increase in the interest in museums and the fact that the museums attract more visitors as a center of attraction and increase the competitive power of the tourism sector. With the introduction of information technologies and the Internet into our lives, it is extremely important that the museums exhibiting cultural heritage keep up with these developments and move to the electronic environment (Oruç, 2016).

Today, world museums have begun to adopt a future-oriented vision that is suitable for the change of the 21st century. The concept of classical museology has changed in a conceptual context with the inclusion of technology-based platforms such as virtual museums, digital museums, augmented reality (AR) and virtual reality (VR). According to the new museum understanding, museums are rapidly advancing on the way of transforming digital and interactive art into environments that enable them to come face to face in a dialectic of a certain look and perception with the work of art, unlike conventional museums (Bostanc1, 2019, p. 38). In the digital age, the boundaries and walls of the museums have been removed, the developing technologies and display strategies have changed and have turned into areas of mental fiction than before (Boyac1, 2019, p. 106; Erbay, 2017).

Considered as the last industrial revolution, Industry 4.0 has shown great advances in the fields of information and technology since 2011 and many businesses in different industries have been competing in many areas from artificial intelligence to augmented reality, from big data to the internet of things. With the spread of technological developments in all areas of life, their use in museums is gradually increasing. As museums keep pace with technological developments, accessibility of museums increases with interactive museums and virtual museum applications and the wishes, interests and skills of new generation visitors are taken into consideration (Okan, 2015, p. 196; Erbay, 2017). Through interactive museum studies, more visitors are tried to be reached through technological applications such as simulators, headsets, virtual reality applications, kiosks, three-dimensional printers, touch systems, and computer rooms within the museum (Mil \& Dirican, 2018, p. 6).

In the research, the applications of industry 4.0 applications in interactive museums were evaluated by a multi-criteria decision-making method. Among the technology applications used in museums, virtual reality, interactive exhibition, easy access to digital vehicles and devices used are evaluated as smart museum criteria. The museums selected as research areas were examined according to the above criteria and the multi-criteria decision-making method. With the widespread use of technology in museums, it is aimed to attract the attention of the masses who are interested in technology and increase the interest in museums and the number of visitors. It is extremely important for museums to keep up with technological developments and to increase their effectiveness at a contemporary and professional level.

\section{Conceptual Framework}

Visiting the museum is a personal need that places a meaning on human existence and creates great changes in human visual perception (Erbay, 2015, p. 23). ICOM (International Museums Committee), established in 1946, has made the definitions of the museums accepted worldwide and changed the definition of museum in parallel with social developments and made updates in the definition. According to ICOM (2019); museums are democratising, inclusive and polyphonic spaces for critical dialogue about the pasts and the future. Acknowledging and addressing the conflicts and challenges of the present, they hold artefacts and specimens in trust for society, safeguard diverse memories for future generations and guarantee equal rights and equal access to heritage for all people. Museums are not for profit. They are participatory and transparent, and work in active partnership with and for diverse communities to collect, preserve, research, interpret, exhibit, and enhance understandings of the world, aiming to contribute to human dignity and social justice, global equality and planetary wellbeing (ICOM, 2019).

Museums have to live in 3 main axes due to their missions, contents and structures. Museums should try to become a destination by carrying out works to "protect the evidence of the past", "carry the cultural 
heritage to the future" and "promote, display and market this inventory from local to global" (Figure 1). The digitalization of information with great speed and the increasing capacity of digital information to increase gradually have brought museums to a point where virtual exhibitions are examined, studied and researched in high-resolution image format on the internet. All these developments enable museums to expand and develop their service range (Güven \& Ersoy, 2016).

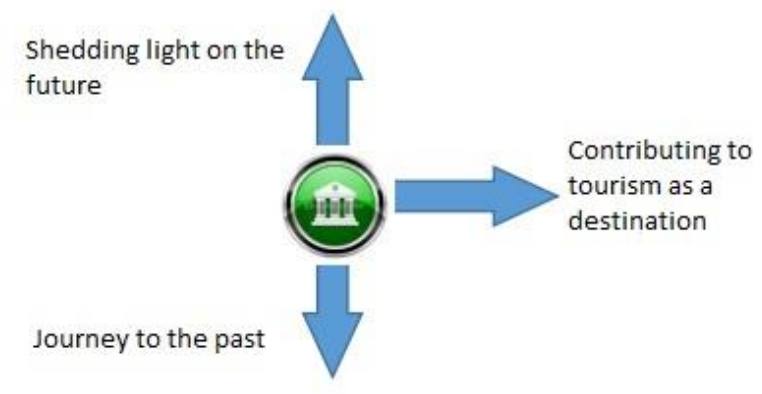

Figure 1. Mission of the Museums (Source: Güven \& Ersoy, 2016)

Among the tourism types, museums, which are examined under culture tourism and where the demand for visitors increases day by day, started to become modernized and technologically equipped buildings with technological developments (Kervankiran, 2014, p. 349-350). The first use of technological elements in museums; Security-related technologies have been used to protect works such as alarms, fire detectors, motion sensors, cameras. Then, the use of technological elements has also become widespread in the fields of inventory records, work tracking, exhibition, lighting and air conditioning. With the use of technological developments in display methods, museums have become more interesting and the modernity of museums has started to be measured by how they use technology. Since the 1990s, the use of collections on the internet, the concept of virtual museums and the use of the internet for museums to communicate with society have become widespread (Yücel, 2012, p. 28). With the use of the internet, museums have been moved to another dimension.

Museums tend not only to passive and virtual relationships by users but also to interactive use. The user therefore actively influences the building of museum knowledge by configuring new paradigms for the museum-visitor relationship. Although the presence of museums on the internet can be visited by more visitors, the absence of virtual space may cause many potential visitor losses (Vaz, Fernandes, \& Veiga, 2018, p. 32). Although the concept of the interactive museum has not been defined yet, many possible names such as the online museum, electronic museum, digital museum, web museum, cyber museum, virtual museum are used for new age museums (Holdgaard, 2011). Interactive museums are created with an emphasis on interactive and experiential presentations that appeal to multiple senses with the participation of visitors, creating a sensory space and facilitating learning. Thus, it is ensured that visitors become a part of the presentation, have a sense of belonging and support what they see visually with different senses. Many alternative sizes such as interactive presentation screens, interactive floors and walls, digital trip screens, interactive books, etc. become interactive museums. It gives visitors the opportunity to examine the works in full detail by touching, enlarging or shrinking the objects or rotating them. In addition, it provides the opportunity to take a photo with a village belonging to the past period or to take pictures with people who lived there, or to visit the visitors alive at that time. Interactive museums provide the opportunity to introduce not only the works in the museum but also many works that have witnessed that era along with that work, and to renew the historical objects and products they display on this screen in the future, and attract visitors to museums again and again (Ekiz, Yerlikaya, \& Kaya, 2018, p. 5).

Touch screens (touch screen interactives) or applications (such as Ipad app) that provide information about the works can present the material of the artwork, where it is made, information such as the purpose of its construction. In presentations using interactive systems, it can also appeal to more visitors by showing a wide range from tactile to auditory. One of the examples of interactive museums in Turkey is the Sak1p Sabanc1 Museum, in which work presentations and providing information about the works enriched with reality elements of interactive design (Ekiz et al. 2018, p. 5; Sertalp, 2017, p. 112).

The changing display methods increase the effect with the cooperation with visitors and cause the curiosity to the museum to increase (Keş \& Başer Akyürek, 2018, p. 97). Exhibition methods in museums 
are moving animation models (mechanical systems with time or motion sensors), audio guides (systems that allow listening, display and language options, and video narration), technology-oriented education (film shows, experimental workshops, educational games that can be played in kiosks (simulation technology creates a universe simulation in the planetarium in Rahmi Koç Museum). Also, applications downloaded to phones (Museum Assist), kiosks for informative and educational purposes, touch tables to promote the works and various applications with motion sensors, tablets or phones with barcode detection (exhibited when it is held, it provides detailed written information about that work, translates it or presents other works similar to that work as a slide show) are used. Finally, internet-oriented systems (used for archive and catalog, advertisement, etc.) are widely used (Sarsilmaz, 2010, p. 46; Oruç, 2016).

Augmented reality (AR) and virtual reality (VR) technology creates a lot of benefits to all actors (tourism businesses, destinations, tourists, museums, etc.) in tourism and meets curiosity, interest, desires and needs. Virtual reality and augmented reality technology create three-dimensional visual objects and virtual environments in tourism, creating tourist businesses, destinations, historical, cultural and architectural sites, museums, etc. It offers the opportunity to experience places in these virtual environments as if they were real (Sarsilmaz, 2010, p. 46; Demirezen, 2019). Augmented reality (AR); A system that provides a direct or indirect view of a physical real-world environment enhanced by computer-generated input, such as information, audio, video, graphics or GPS data (Kounavis, Kasimati, \& Zamani, 2012, p. 1; Özgan, 2012, p. 7; Osterlund \& Lawrence, 2012, p. 149; Johnston, 2014, p. 24; Bilici, 2015, p. 30; Madsen, 2016, p. 9-10; Nelson, 2016, p. 2; Sheridan, 2016, p. 76; Köse, 2017, p. 7; Yagol, 2018, p. 5). Virtual reality (VR) is a three-dimensional simulation model that gives its participants a feeling of realism and enables the opportunity of mutual communication with a dynamic environment created by computers (Bayraktar \& Kaleli, 2007, p. 1). Virtual reality technology consists of a headmounted displays (HMD) and a glove device called DataGlove. The head-mounted display provides separate images for the user to see, thus giving him a natural stereo image of a three-dimensional environment (Demirezen, 2019, p. 4). Systems designed with virtual reality technology significantly increase the comprehension and perception power of the user with the feeling of being real.

The websites of famous museums around the world provide all kinds of information about the history of the museum, the features of the museum, the works in the museum, and even provide virtual trips in museum halls and questioning opportunities in the museum database (Baştanlar et al. 2006). Virtual museums are museums that contain digital objects and information about them, using different media facilities, provide uninterrupted communication with visitors, go beyond the usual communication methods to meet various forms of access, and do not need a physical place to enable worldwide access (Schweibenz, 2004, p. 3). Virtual museology is a type of museum that best reflects the modern museum image and content. Although it draws visitors from its own countries by using modern museum technologies, it also attracts visitors from various countries of the world (Okan, 2015, p. 191). In addition, in order to increase the interest in museums, many museums in the world keep up with technological developments and can reach visitors with virtual museum activities. Especially timely epidemic has increased the number of visitors to the many virtual museums in the world and Turkey. Among the most visited virtual museums in the world, Pinacoteca di Brera- Milan, Galleria degli Uffizi- Firenze, Musei Vaticani-Roma, Museo Archeologico-Atene, Prado-Madrid, Louvre-Parigi, British Museum- London, Metropolitan Museum- New York, Hermitage-San Pietroburgo can be exemplified. The top five most visited museums in Turkey are Göbeklitepe Archaeological Site (3.383.985 visitors), War of Independence Museum (1.869.319 visitors), Ephesus Archaeological Site (1.350.742 visitors), Troy Museum (1.100.147 visitors), Museum of Anatolian Civilizations (1.031.447 visitors) (www. turizmgunlugu.com). In addition, the museum offers interactive technologies by the year 2019 in Turkey are listed below. 
Table 1. Museums Applying Interactive Technologies

\author{
1.Burdur Museum \\ 2.Eskişehir Eti Archaeology Museum \\ 3.Zonguldak Mining Museum \\ 4.Antalya Museum \\ 5.Lycia Civilizations Museum \\ 6. Gaziantep Zeugma Museum \\ 7. Diyarbakır Museum \\ 8. Çanakkale Troia Museum \\ 9. Mersin Museum \\ 10. Corum Museum \\ 11. Aydın Archaeology Museum \\ 12. Hatay Archaeology Museum \\ 13.Museum of Anatolian Civilizations
}

\author{
14. Ankara Etnography Museum \\ 15. Çankırı Museum \\ 16.Topkapı Palace Museum /Weapon Section (İstanbul) \\ 17. Topkap1 Carpet Museum (İstanbul) \\ 18. Kahramanmaraș Museum \\ 19. Konya Mevlana Museum Dervish Cells \\ 20. Yeşil Efendi Mansion (Eskişehir) \\ 21. Knowledge Culture and Promotion Center (Mardin) \\ 22. Clock Tower (Bursa) \\ 23.Sakıp Sabanc1 Museum (İstanbul) \\ 24. Ankara State Painting and Sculpture Museum \\ 25. Rahmi Koç Museum (İstanbul)
} (Ankara)

Source: Şardan, 2019, p. 61; Sucaklı, 2019, p. 73.

Today, many museums benefit from "digitalization" based on information and communication technology (ICT). Developments in mobile and web information technologies cause a popular museum information service group, each created by personalized services within the hotel for museum visitors. It allows a visitor to access information about the surrounding exhibitions with a personal mobile device (such as a smartphone). The flow of information is one-way, from digital cultural heritage to visitors. In this case, the services do not support joint action and information generation. In particular, users of the Smart Museum system (Ruotsalo et al. 2013) can get detailed explanations and multimedia content related to individual objects. The system provides objects based on a user profile and content information (for example, the user's physical location and motivation). The system can receive information from the Web about a particular object and related content. The user accesses both suggestions and related content. Besides, the system provides on-site image streaming for the content to which the video is added along with the sound synthesis (Korzun, Varfolomeyev, Yalovitsyna, \& Volokhova, 2017, p. 347).

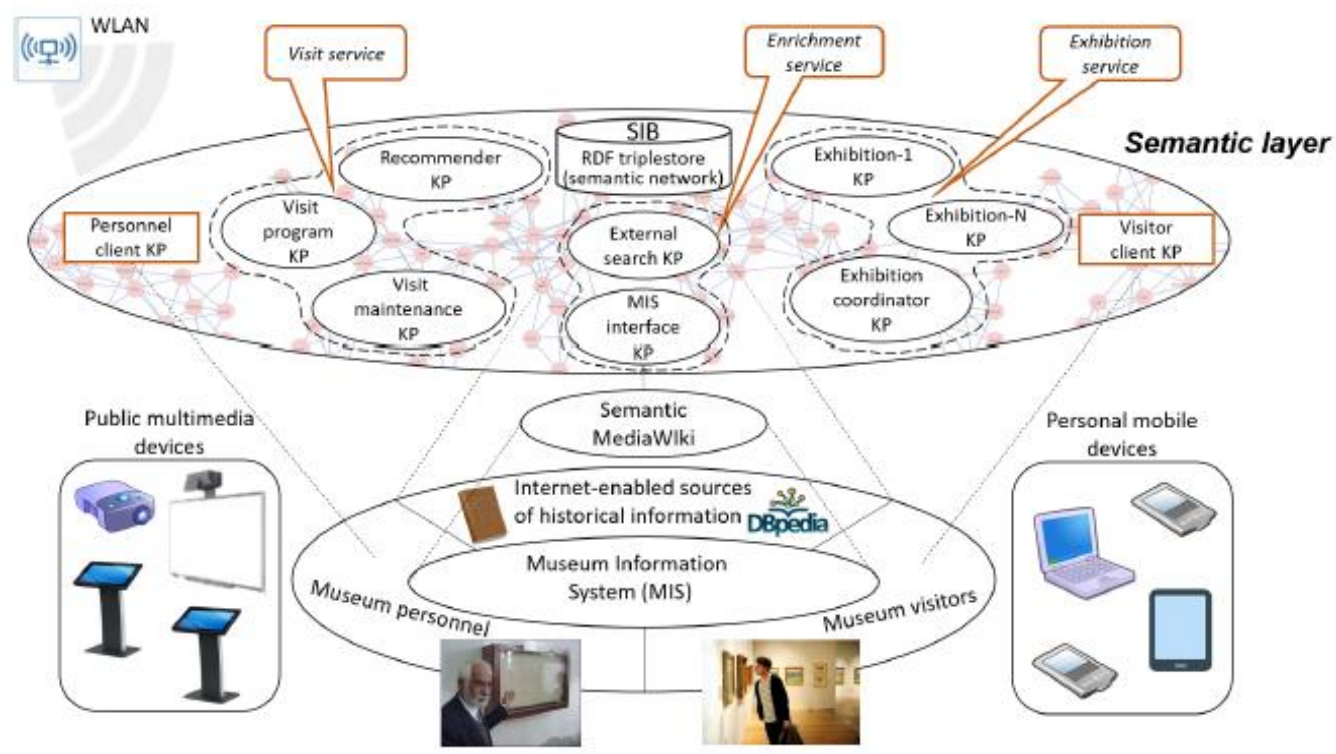

Figure 2. Smart Museum Concept (Source: Korzun, Yalovitsyna, \& Volokhova, 2018).

Among the studies carried out in the literature on interactive museums, Sucakl (2019) gave examples of the importance of museum and museology in terms of tourism and the use and role of augmented reality technology for the sustainability of museology and museums that apply this technology. He held a meeting with the official of the Sakıp Sabanc1 Museum, who first applied this technology. He concluded that augmented reality technology plays an important role in the development of museology and in modern museology. Keş and Başer Akyürek (2018) talked about the definition and history of museums and mentioned that technology should be included in museums for new generation individuals. Also examined in interactive museums in Turkey and increasing the number of Dunay and the few interactive museums has mentioned that the development of children's museum culture. Oruç (2016) examined the 
development of virtual museums, the definition and types of virtual museums, positive and negative approaches to virtual museums.

The relationship between technology and exhibition has been examined in the literature (Şardan, 2019; Boyraz, 2013). In his study, Boyraz (2013) discussed the concepts of technology and exhibition within the framework of museology and especially examined the relationship between museum technology and exhibition. He explained that the differences in museum technologies and exhibitions and the changes made in museums significantly affect the relationship of the museum with its visitors. In his study, Sarsilmaz (2010) examined the use of technology in museums and the meaning of the virtual museum. Despite the use of technology in a very efficient manner in museums in many museums in Europe in museums in Turkey have realized that a lot of active use. As a result of the literature review, no study has been found that examines the smart museum criteria in detail. For this reason, the study is important in terms of filling the gap in the literature.

\section{Methodology}

The multi-criteria decision-making technique (AHP-Analytic Hierarchy Process) was developed by Saaty in the 1970s for the solution of complex multi-criteria decision-making problems. When there are criteria that include more than one quality and quantity in a decision-making process, such decisionmaking situations are called "multi-criteria decision making" (Turan, 2014, p. 15). Human nature tends to evaluate how important, dominant or preferable criteria and options are relative to each other with binary comparison (Özgörmüş, Mutlu, \& Güner, 2005). From this point of view, AHP is a technique that can take into account both objective and subjective evaluation criteria and needs the opinions of the decisionmaker in determining the relative importance levels related to all criteria (Önder \& Önder, 2015, p. 22-23). This makes AHP method more powerful than other multi-criteria decision making methods. Accordingly, in this study, AHP method, one of the multi-criteria decision making methods, was used in order to compare the criteria of smart museums and applications in museums. In the research, first of all, digitalization in tourism, digital museums and smart museums were searched and criteria were created for smart museums. When the data were examined, it was determined that more than one factor was effective in choosing a smart museum. These elements are as follows;

- Easy Access Criteria in Digital Vehicles; where it is, visual information, artifact information, virtual tour information, interactive infrastructure information

- Virtual Trip Criteria; ease of application, trip area density, 3D photo abundance, 3D information abundance, outdoor display, 3D glasses

- Interactive Exhibition Criteria; AG application, touch screen, information, audio guide, other

- Used Devices Criteria; audio guide, location-direction information, information boards, kiosk density

According to Saaty (2008), decision-makers compare the criteria and sub-criteria by using questionnaires prepared in accordance with a 1-9 scale (Table 2). The priority order of decision alternatives is obtained by evaluating all criteria (Önder \& Önder, 2015, p. 22-23).

Table 2. Significance Levels Used in Comparisons

\begin{tabular}{lll}
\hline $\begin{array}{l}\text { Importance } \\
\text { Values }\end{array}$ & \multicolumn{1}{c}{ Definition } & \multicolumn{1}{c}{ Value Definitions } \\
\hline 1 & Equally Important & Both factors are of the same importance. \\
\hline 3 & Moderately Important & $\begin{array}{l}\text { According to experience and judgement, one factor is more important } \\
\text { than the other factor. }\end{array}$ \\
\hline 5 & Strongly Important & One factor is strongly more important than the other. \\
\hline 7 & Very Strongly Important & One factor is highly important than the other. \\
\hline 9 & Absolutely Important & One of the factors is very important to the other. \\
\hline $2,4,6,8$ & Represents Intermediate Values & $\begin{array}{l}\text { They are the intermediate values of the degrees in the above } \\
\text { explanations in the choice between the two factors. }\end{array}$ \\
\hline
\end{tabular}

Source: Saaty, 2008, p. 86. 


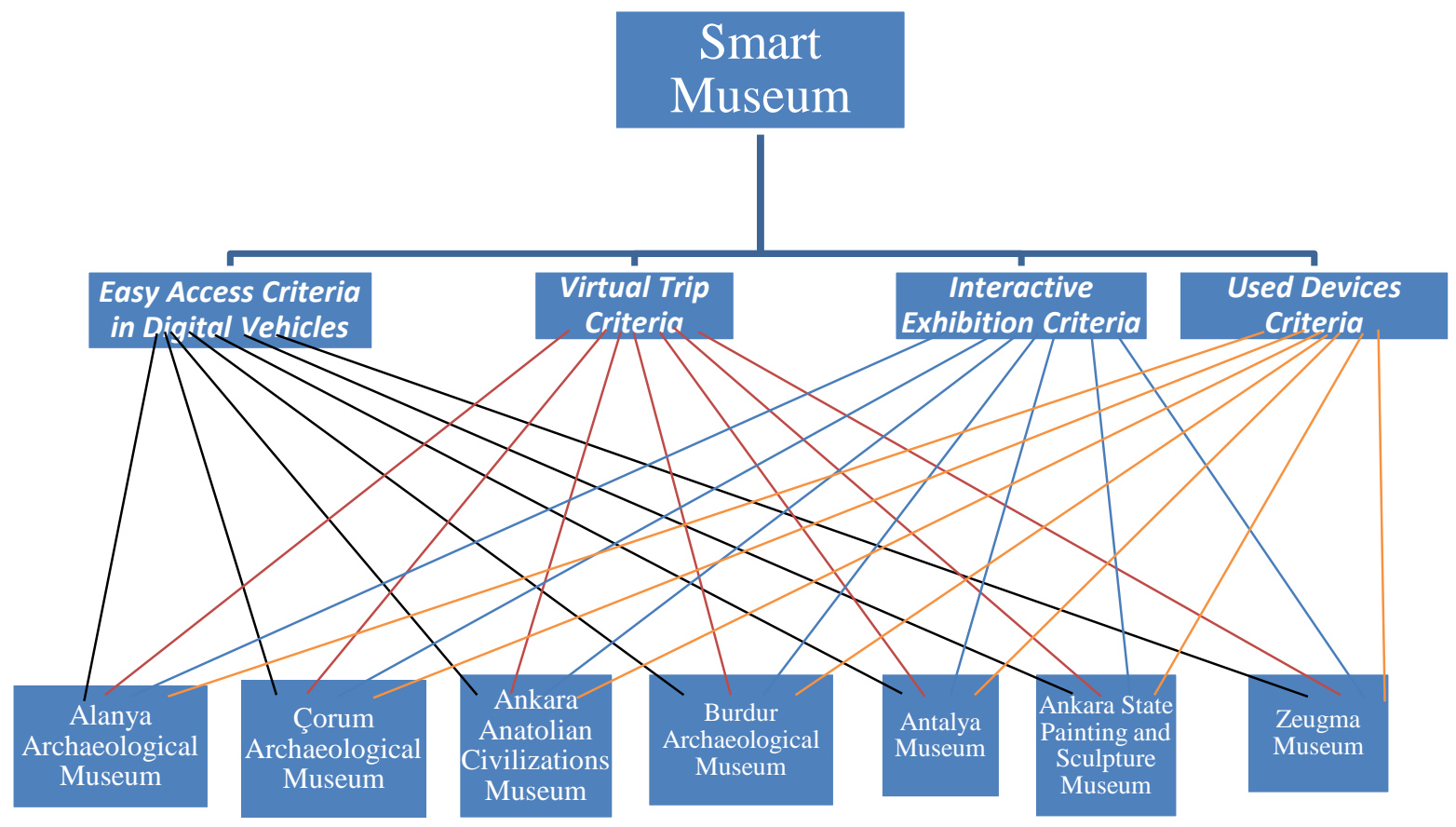

Figure 3. Analytical Hierarchy Model of Research

Within the scope of the research, AHP (Analytic Hierarchy Process) method was preferred in order to analyze according to multiple criteria. Because the AHP method provides the opportunity to evaluate more than one criterion under a single topic (Önder \& Önder, 2015, p. 22).

Table 3. Research Model

\section{Research Model}

Defining the decision-making problem, determining the purpose,

Listing the decision criteria required to achieve the goal

Identifying possible alternatives

Creating the hierarchical structure of the decision problem

Determining the importance of binary comparisons for each level of the hierarchy

Calculation of priorities by comparing alternatives according to criteria

Compliance analysis

Sorting alternatives according to relative priority values

Making sensitivity analysis

Source: Önder \& Önder, 2015, p. 23.

The museums which are subject to the study were accessed from the work of Keş and Akyürek (2018), who provided information about the digitalization process, and the page of the reo-tek company that produces interactive exhibition units for museums. According to the stages indicated in Table 3 , a questionnaire form has been created for the criteria that affect the selection of Alanya Archeology Museum, Çorum Archeology Museum, Ankara Anatolian Civilizations Museum, Burdur Archeology Museum, Antalya Museum, Ankara State Painting and Sculpture Museum and Zeugma Museum as a smart museum. The research data were obtained through face-to-face and telephone interviews with 10 tourism experts. Tourism experts included in the study consist of 4 female and 6 male academicians working at Selçuk University and Isparta University of Applied Sciences. Care has been taken to ensure that the field experts included in the research work on digitalization in tourism. The data were recorded in the Super Decision program according to the following hierarchical structure. 2018);

Solution stages with AHP work as follows (Önder \& Önder, 2014: 23-24; Göral \& Tengilimoğlu,

Step 1: The decision-making problem is defined and the goal is determined. 
Step 2: Decision criteria required to achieve the goal are determined.

Step 3: Possible decision alternatives are determined.

Step 4: The hierarchical structure of the decision problem is created.

Step 5: Binary comparison of criteria for each level of the hierarchy and using eigenvectors to determine the importance of the criteria. At this stage, the comparison matrix between criteria is a dimensional square matrix. The matrix components on the diagonal of this matrix take the value 1 . The comparison matrix is shown below.

$$
\boldsymbol{A}=\left[\begin{array}{cccc}
a_{11} & a_{12} & \ldots & a_{1 n} \\
a_{21} & a_{22} & \ldots & a_{2 n} \\
\cdot & & & \cdot \\
\cdot & & & \cdot \\
\cdot & & & \cdot \\
a_{n 1} & a_{n 2} & \ldots & a_{n n}
\end{array}\right]
$$

Comparison of criteria is made one to one and mutually according to the importance values they have with respect to each other. The AHP comparison scale in Table 2 is used for the one-to-one comparison of the criteria. In order to determine the weights of these criteria in the whole, in other words the percentage significance distributions, the column vectors that make up the comparison matrix are used and the $\mathrm{B}$ column vector with $\mathrm{n}$ and $\mathrm{n}$ components is created. This vector is shown below:

$$
B,-\left[\begin{array}{c}
b_{11} \\
b_{x-1} \\
- \\
- \\
b_{n 1}
\end{array}\right]
$$

The formula is used to calculate the B column vectors:

$$
b_{i j}=\frac{a_{i j}}{\sum_{i=1}^{n} a_{i j}}
$$

When the steps described above are repeated in the other evaluation criteria, the B column vector will be obtained as much as the number of criteria. When the number of $\mathrm{N}$ columns of $\mathrm{B}$ column vectors are combined in a matrix format, the $\mathrm{C}$ matrix shown below will be created:

$$
C=\left[\begin{array}{cccc}
c_{11} & c_{12} & \ldots & c_{1 n} \\
c_{21} & c_{22} & \ldots & c_{2 n} \\
\cdot & & & \vdots \\
\cdot & & & \vdots \\
c_{n 1} & c_{n 2} & \ldots & c_{n n}
\end{array}\right]
$$

By using the $\mathrm{C}$ matrix, percentage significance distributions showing the relative importance values of the criteria can be obtained. For this, as shown in formula (1), the arithmetic average of the row components forming the $\mathrm{C}$ matrix is taken and the column vector $\mathrm{W}$ called the Priority Vector is obtained. The $\mathrm{W}$ vector is shown below. 


$$
\text { (1) } \quad w_{i}=\frac{\sum_{j=1}^{n} c_{i j}}{n} \quad W=\left[\begin{array}{c}
w_{1} \\
w_{2} \\
\cdot \\
\cdot \\
\cdot \\
w_{n}
\end{array}\right]
$$

Step 6: The consistency of the comparison matrices obtained in the previous step is investigated. AHP provides the opportunity to test the consistency of the obtained Consistency Rate (CR) with the priority vector found and therefore the one-to-one comparisons between the criteria.

$$
D=\left[\begin{array}{cccc}
a_{11} & a_{12} & \ldots & a_{1 n} \\
a_{21} & a_{22} & \ldots & a_{2 n} \\
\cdot & & & \cdot \\
\cdot & & & \cdot \\
\cdot & & & \cdot \\
a_{n 1} & a_{n 2} & \ldots & a_{n n}
\end{array}\right] x\left[\begin{array}{c}
w_{1} \\
w_{2} \\
\cdot \\
\cdot \\
\cdot \\
w_{n}
\end{array}\right]
$$

The value (E) for each evaluation criterion is obtained from the division of the reciprocal elements of the column vector $\mathrm{D}$ and column vector $\mathrm{W}$ found. The arithmetic mean (2) of these values gives the basic value $(\lambda)$ for the comparison. After calculating $\lambda$, the Consistency Indicator (CI) can be calculated using the formula (3). Dividing by the standard correction value (4) CR is obtained.

$$
\lambda=\frac{\sum_{i=1}^{n} E_{i}}{n} \text { (2) } \quad C I=\frac{\lambda-n}{n-1} \quad \text { (3) } \quad C R=\frac{C I}{R I}
$$

Step 7: The importance (weights) of the alternatives and criteria are determined. The alternative with the highest weight is the best alternative, the criterion with the highest weight is determined as the most important criterion.

While creating the AHP hierarchy model, seven museums were compared with each other with the criteria that affect being a smart museum. The data obtained from the people within the scope of the study were graded according to the comparison table of all criteria and museums using the "Super Decisions" program (for example, see Figure 4). 


\begin{tabular}{|c|c|c|c|c|c|c|c|c|c|c|c|c|c|c|c|c|c|c|c|c|}
\hline 1. & 1. Alanya & $>=9.5$ & 9 & 8 & 7 & 6 & 5 & 4 & 3 & 2 & 2 & 3 & 4 & 5 & \begin{tabular}{l|l}
6 & 7
\end{tabular} & 8 & 9 & $>=9.5$ & No comp. & 2. Çorum \\
\hline 2. & 1. Alanya & $s=9.5$ & 9 & 8 & 7 & 6 & 5 & 4 & 3 & 2 & 2 & 3 & 4 & 5 & 6 . 7 & 8 & 9 & $>=9.5$ & No comp. & 3. Anadolu \\
\hline 3. & 1. Alanya & $>=9.5$ & 9 & 8 & 7 & 6 & 5 & 4 & 3 & 2 & 2 & 3 & 4 & 5 & $\begin{array}{ll}6 & 7\end{array}$ & 8 & 9 & $>=9.5$ & No comp. & 4. Burdur \\
\hline 4. & 1. Alanya & $p=9.5$ & 9 & 8 & 7 & 6 & 5 & 4 & 3 & 2 & 2 & 3 & 4 & $5 \epsilon$ & \begin{tabular}{l|l}
6 & 7
\end{tabular} & 8 & 9 & $>=9.5$ & No comp. & 5. Antalya \\
\hline 5. & 1. Alanya & $>=9.5$ & 9 & 8 & 7 & 6 & 5 & 4 & 3 & 2 & 2 & 3 & 4 & 5 & \begin{tabular}{l|l}
6 & 7
\end{tabular} & 8 & 9 & $>=9.5$ & No comp. & 6. Ankara Devle- \\
\hline 6. & 1. Alanya & $p=9.5$ & 9 & 8 & 7 & 6 & 5 & 4 & 3 & 2 & 2 & 3 & 4 & 5 & \begin{tabular}{l|l}
6 & 7
\end{tabular} & 8 & 9 & $>=9.5$ & No comp. & 7. Zeugma \\
\hline 7. & 2. Çorum & $>=9.5$ & 9 & 8 & 7 & 6 & 5 & 4 & 3 & 2 & 2 & 3 & 4 & 5 & \begin{tabular}{l|l}
6 & 7
\end{tabular} & 8 & 9 & $>=9.5$ & No comp. & 3. Anadolu \\
\hline 8. & 2. Çorum & $p=9.5$ & 9 & 8 & 7 & 6 & 5 & 4 & 3 & 2 & 2 & 3 & 4 & 5 & \begin{tabular}{l|l}
6 & 7
\end{tabular} & 8 & 9 & $>=9.5$ & No comp. & 4. Burdur \\
\hline 9. & 2. Çorum & $>=9.5$ & 9 & 8 & 7 & 6 & 5 & 4 & 3 & 2 & 2 & 3 & 4 & 5 & \begin{tabular}{l|l}
6 & 7
\end{tabular} & 8 & 9 & $>=9.5$ & No comp. & 5. Antalya \\
\hline 10. & 2. Çorum & $>=9.5$ & 9 & 8 & 7 & 6 & 5 & 4 & 3 & 2 & 2 & 3 & 4 & 5 & \begin{tabular}{l|l}
6 & 7
\end{tabular} & 8 & 9 & $>=9.5$ & No comp. & 6. Ankara Devle \\
\hline 11. & 2. Corum & $>=9.5$ & 9 & 8 & 7 & 6 & 5 & 4 & 3 & 2 & 2 & 3 & 4 & 5 & $\begin{array}{ll}6 & 7\end{array}$ & 8 & 9 & $>=9.5$ & No comp. & 7. Zeugma \\
\hline 12. & 3. Anadolu & $s=9.5$ & 9 & 8 & 7 & 6 & 5 & 4 & 3 & 2 & 2 & 3 & 4 & 5 & \begin{tabular}{l|l}
6 & 7
\end{tabular} & 8 & 9 & $>=9.5$ & No comp. & 4. Burdur \\
\hline 13. & 3. Anadolu & $>=9.5$ & 9 & 8 & 7 & 6 & 5 & 4 & 3 & 2 & 2 & 3 & 4 & 5 & \begin{tabular}{l|l}
6 & 7
\end{tabular} & 8 & 9 & $>=9.5$ & No comp. & 5. Antalya \\
\hline 14. & 3. Anadolu & $>=9.5$ & 9 & 8 & 7 & 6 & 5 & 4 & 3 & 2 & 2 & 3 & 4 & 5 & \begin{tabular}{l|l}
6 & 7 \\
\end{tabular} & 8 & 9 & $>=9.5$ & No comp. & 6. Ankara Devle \\
\hline 15. & 3. Anadolu & $>=9.5$ & 9 & 8 & 7 & 6 & 5 & 4 & 3 & 2 & 2 & 3 & 4 & 5 & \begin{tabular}{l|l}
6 & 7 \\
\end{tabular} & 8 & 9 & $>=9.5$ & No comp. & 7. Zeugma \\
\hline 16. & 4. Burdur & $>=9.5$ & 9 & 8 & 7 & 6 & 5 & 4 & 3 & 2 & 2 & 3 & 4 & 5 & \begin{tabular}{l|l}
6 & 7 \\
\end{tabular} & 8 & 9 & $>=9.5$ & No comp. & 5. Antalya \\
\hline 17. & 4. Burdur & $>=9.5$ & 9 & 8 & 7 & 6 & 5 & 4 & 3 & 2 & 2 & 3 & 4 & 5 & \begin{tabular}{l|l}
6 & 7 \\
\end{tabular} & 8 & 9 & $>=9.5$ & No comp. & 6. Ankara Devle- \\
\hline 18. & 4. Burdur & $x=9.5$ & 9 & 8 & 7 & 6 & 5 & 4 & 3 & 2 & 2 & 3 & 4 & 5 & $6 \sqrt{6}$ & 8 & 9 & $>=9.5$ & No comp. & 7. Zeugma \\
\hline 19. & 5. Antalya & $>=9.5$ & 9 & 8 & 7 & 6 & 5 & 4 & 3 & 2 & 2 & 3 & 4 & 5 & 67 & 8 & 9 & $>=9.5$ & No comp. & 6. Ankara Devle- \\
\hline 20. & 5. Antalya & $p=9.5$ & 9 & 8 & 7 & 6 & 5 & 4 & 3 & 2 & 2 & 3 & 4 & 5 & \begin{tabular}{l|l}
6 & 7
\end{tabular} & 8 & 9 & $>=9.5$ & No comp. & 7. Zeugma \\
\hline 21. & kara Devle & $>=9.5$ & 9 & 8 & 7 & 6 & 5 & 4 & 3 & 2 & 2 & 3 & 4 & 5 & 7 & 8 & 9 & $>=9.5$ & No comp. & 7. Zeugma \\
\hline
\end{tabular}

Figure 4. Binary Comparison Survey Image

Inconsistency rates should be checked while creating a hierarchy and making binary comparisons. The Consistency Ratio is calculated for each pairwise comparison matrix, and the upper limit of the ratio proposed by Saaty (2008) is defined as 0.10 . If this ratio calculated for the criteria is below 0.10 , it is accepted that the criteria exhibit sufficient consistency and the evaluation can continue (cited in Palaz \& Kovanc1, 2008, p. 56). In the study, the inconsistency rates of the comparison results of all criteria were found to be less than 0.1 .

\section{Findings}

Below are the data results that affect the analytical hierarchical selection process of Alanya Archeology Museum, Çorum Archeology Museum, Ankara Anatolian Civilizations Museum, Burdur Archeology Museum, Antalya Museum, Ankara State Painting and Sculpture Museum and Zeugma Museums according to the smart museum criteria. 
Table 4. Factors and Data Affecting Smart Museum Choices

\begin{tabular}{|c|c|c|c|c|c|c|c|}
\hline Criteria & 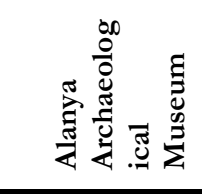 & 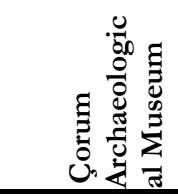 & 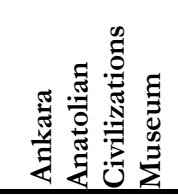 & 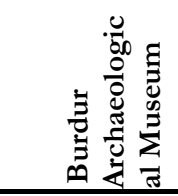 & 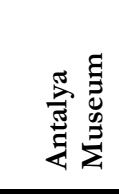 & 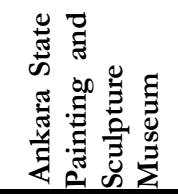 & 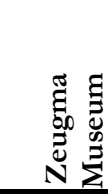 \\
\hline $\begin{array}{l}\text { Easy Access } \\
\text { in Digital } \\
\text { Vehicles }\end{array}$ & 0.085 & 0.219 & 0.242 & 0.124 & 0.210 & 0.112 & 0.047 \\
\hline $\begin{array}{l}\text { Virtual Reality } \\
\text { Applications }\end{array}$ & 0.507 & 0.591 & 0.570 & 0.676 & 0.300 & 0.641 & 0.303 \\
\hline $\begin{array}{l}\text { Interactive } \\
\text { Exhibition }\end{array}$ & 0.203 & 0.142 & 0.107 & 0.070 & 0.131 & 0.165 & 0.378 \\
\hline Used Devices & 0.203 & 0.046 & 0.079 & 0.128 & 0.357 & 0.079 & 0.270 \\
\hline
\end{tabular}

According to the smart museum criteria of Alanya Archeology Museum, it is seen that the most important element is virtual reality applications with a value of 0.507 . Other effective elements are listed as an interactive exhibition, used devices. The least affecting factor for being a smart museum is easy to access to digital vehicles (0.085). It is seen that the most important factor affecting the status of Çorum Archeology Museum as a smart museum is virtual reality applications with a value of 0.591 . Other factors that are effective are easy access to digital vehicles (0.219), interactive exhibition (0.142) and used devices (0.046). While the most important factor affecting the status of Ankara Anatolian Civilizations (0.570), Burdur Archeology (0.676) and Ankara State Painting and Sculpture Museum (0.641) being a smart museum is virtual reality applications, the criterion of used devices in the Antalya Museum (0.357) and interactive exhibition in the Zeugma Museum (0.378) seem to be effective.

\begin{tabular}{|c|c|c|c|c|c|c|c|c|}
\hline \multirow{2}{*}{\multicolumn{7}{|c|}{$\begin{array}{l}\text { Comparisons wit "1. Dijital Ulaşım" node in "Alternatifler" cluster } \\
\text { 2. Çorum is } 6 \text { times more important than 1. Alanya }\end{array}$}} & \multicolumn{2}{|c|}{ Inconsistency: 0.04489} \\
\hline & & & & & & & 1. Alanya & 0.02814 \\
\hline Inconsistency & 2. Çorum & 3. Anadolu & 4. Burdur & 5. Antalya & 6. Ankara & 7. Zeugma & 2. Çorum & 0.21669 \\
\hline 1. Alanya & $\uparrow 5.9999$ & $1 \uparrow 8$ & $\uparrow 2$ & $\uparrow 5$ & $\uparrow 3.0000$ & $\uparrow 5$ & 3. Anadolu & 0.36700 \\
\hline 2. Corum & & 1 2 & $\leftarrow 5$ & $\leftarrow 3$ & $\leftarrow 2$ & $\leftarrow 2$ & 4. Burdur & 0.03687 \\
\hline 2. दुणा व & & $1 T<$ & 15 & +13 & 12 & +2 & 5. Antalya & 0.13971 \\
\hline 3. Anadolu & & & $\leftarrow 8$ & $\leftarrow 4$ & $\leftarrow 6$ & $\leftarrow 3$ & 6. Ankara & 0.06282 \\
\hline 4. Burdur & & & & $\uparrow 5$ & $\uparrow 2$ & $\uparrow 5$ & 7. Zeugma & 0.14877 \\
\hline 5. Antalya & & & & & $\leftarrow 4$ & $\leftarrow 1$ & & \\
\hline 6. Ankara & & & & & & 个 4 & & \\
\hline
\end{tabular}

Figure 5. Comparison Matrix of Museums by Easy Access Criteria in Digital Vebicles

The number, which is the matrix element, indicates the dominance value of the criteria, and the direction of the arrow indicates the dominant criterion. Arrows pointing left in the matrix, according to the criteria on the left side; The arrows pointing upwards show that the criteria above are more important than the criteria on the left (Önder \& Önder, 2015, p. 50). In Figure 5, museums are compared according to the criterion of "easy access in digital vehicles". It is seen that Alanya Museum is weak compared to other museums in terms of easy access in digital vehicles. It is seen that the Anatolian Civilizations Museum is more dominant than all other museums. It is seen that Ankara State Museum of Painting and Sculpture is dominant only from Burdur Archeology and Alanya Archeology Museum. 


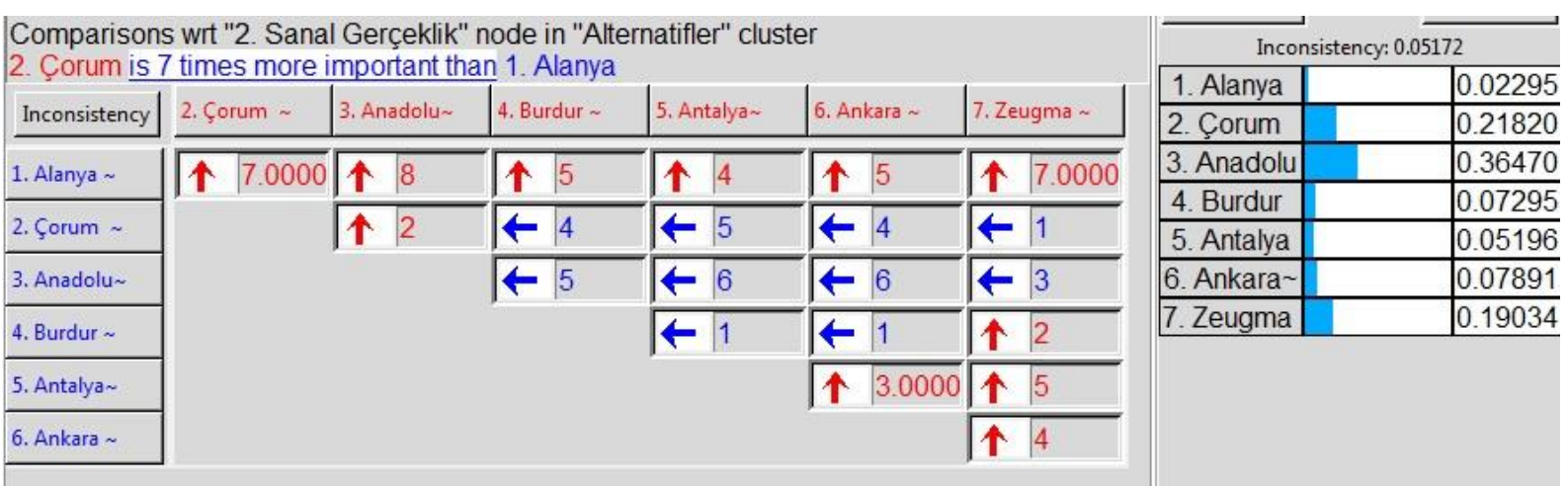

Figure 6. Comparison Matrix of Museums According to Virtual Reality Applications Criteria

In Figure 6, museums are compared according to the "virtual reality applications" criteria. It is seen that virtual reality applications are the weakest in Alanya Museum compared to other museums. Zeugma Museum, on the other hand, was found to be more dominant than Antalya Museum, Ankara State and Art Museum, Burdur and Alanya Museums. It has been concluded that Ankara State Painting and Sculpture Museum is more dominant than Burdur Museum and Alanya Museum.

\begin{tabular}{|c|c|c|c|c|c|c|c|c|}
\hline \multirow{2}{*}{\multicolumn{7}{|c|}{$\begin{array}{l}\text { Comparisons wrt " } 3 \text {. Interaktif Sergileme" node in "Alternatifler" cluster } \\
\text { 2. Corum is } 6 \text { times more important than 1. Alanya }\end{array}$}} & \multicolumn{2}{|c|}{ Inconsistency: 0.05559} \\
\hline & & & & & & & 1. Alanya & 0.02712 \\
\hline Inconsistency & 2. Çorum & 3. Anadolu $\sim$ & 4. Burdur & 5. Antalya & 6. Ankara & 7. Zeugma & 2. C.orum & 0.10163 \\
\hline 1. Alanya & \begin{tabular}{|l|l|}
$\uparrow$ & 5.9999 \\
\end{tabular} & 个 8 & $\leftarrow 1$ & $\uparrow 5$ & $\uparrow \quad 3.0000$ & $\uparrow 8$ & 3. Anadolu & 0.27201 \\
\hline 2. Çorum & & & $1 \div 3$ & $\leftarrow 1$ & - 1 & - 300000 & 4. Burdur & 0.03215 \\
\hline 2. दुण & & $\mathbf{T}$ & 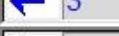 & | & $>1$ & 3.0000 & 5. Antalya & 0.11600 \\
\hline 3. Anadolu & & & $\leftarrow 7$ & $\leftarrow 4$ & $\leftarrow 7$ & $\uparrow 3.0000$ & 6. Ankara - & 0.05899 \\
\hline 4. Burdur & & & & \begin{tabular}{l|l}
$\uparrow$ & 4
\end{tabular} & $\uparrow 2$ & $\uparrow 8$ & 7. Zeugma & 0.39209 \\
\hline 5. Antalya & & & & & $\leftarrow 4$ & $\uparrow 5$ & & \\
\hline 6. Ankara & & & & & & ^ 5.9999 & & \\
\hline
\end{tabular}

Figure 7. Comparison Matrix of Museums According to Interactive Exbibition Criteria

In Figure 7, museums are compared according to the "interactive exhibition" criteria. According to the interactive exhibition criteria, it has been observed that Alanya Museum is more dominant than Burdur Museum. Also, it has been determined that Antalya Museum is more dominant than Burdur Museum and Alanya Museum. While Zeugma Museum is seen to be more dominant than all other museums, it is understood that the weakest museum is the Alanya Museum according to the interactive exhibition criterion.

\begin{tabular}{|c|c|c|c|c|c|c|c|c|}
\hline \multirow{2}{*}{\multicolumn{7}{|c|}{$\begin{array}{l}\text { Comparisons wrt " } 4 \text {. Kullanilan Cihazlar" node in "Alternatifler" cluster } \\
\text { 2. Çorum is } 4 \text { times more important than } 1 \text {. Alanya }\end{array}$}} & \multicolumn{2}{|c|}{ Inconsistency: 0.04889} \\
\hline & & & & & & & 1. Alanya & 0.02804 \\
\hline Inconsistency & 2. Çorum & 3. Anadolu $\sim$ & 4. Burdur & 5. Antalya & 6. Ankara & 7. Zeugma & 2. Corum & 0.09813 \\
\hline 1. Alanya & $\uparrow 4$ & 个 7.0000 & $\uparrow 2$ & \begin{tabular}{l|l}
1 & 5
\end{tabular} & $\begin{array}{ll}1 \uparrow 2 \\
\end{array}$ & 个 8 & 3. Anadolu & 0.32101 \\
\hline 2. Çorum & & ^ 4 & $\leftarrow 4$ & $\uparrow 3.0000$ & $<4$ & 1 4 & 4. Burdur & 0.03877 \\
\hline 3. Anadolu & & & 67 & $\leqslant 4$ & 47 & $<1$ & & $\frac{0.15220}{0.03706}$ \\
\hline & & & & & & & 7 7еияma & 0.32480 \\
\hline 4. Burdur & & & & 14 & $\leftarrow 1$ & $\uparrow 7.0000$ & 1. Leugina & \\
\hline 5. Antalya & & & & & $\leftarrow 6$ & $\uparrow 4$ & & \\
\hline 6. Ankara & & & & & & $\begin{array}{l}17.0000 \\
\end{array}$ & & \\
\hline
\end{tabular}

Figure 8. Comparison Matrix of Museums According to Used Devices Criteria

Museums are compared according to the "used devices" criteria in Figure 8. It is seen that the museum with the best opportunities according to the used device criterion is the Museum of Anatolian Civilizations. It is seen that the Zeugma Museum is more dominant than the other museums, except the Museum of Anatolian Civilizations. Alanya Museum is seen to be the weakest museum. 
Table 5. Smart Museum Choices According to AHP Technique

\begin{tabular}{ll}
\hline Museums & Score \\
\hline Alanya Archaeological Museum & 0.006 \\
Çorum Archaeological Museum & 0.045 \\
Ankara Anatolian Civilizations Museum & 0.085 \\
Burdur Archaeological Museum & 0.013 \\
Antalya Museum & 0.022 \\
Ankara State Painting and Sculpture Museum & 0.017 \\
Zeugma Museum & 0.060 \\
\hline
\end{tabular}

In the Table 5 above, the smart museum selection results according to the multi-criteria decision making technique for the museums are included. Table 5 shows which museum has more smart museum criteria. It is seen that the most smart museum elements take place at Ankara Anatolian Civilizations Museum (0.085) and Zeugma Museum (0.060). Later, they are Çorum Archeology Museum (0.045), Antalya Museum (0.022), Ankara State Painting and Sculpture Museum (0.017), Burdur Archeology Museum (0.013) and Alanya Archeology Museum (0.006) relatively.

Table 6. Choices of Intelligent Museum Criteria According to AHP Technique

\begin{tabular}{ll}
\hline Criteria & Score \\
\hline Easy Access in Digital Vehicles & 0.079 \\
Virtual Reality Applications & 0.262 \\
Interactive Exhibition & 0.111 \\
Used Devices & 0.046 \\
Inconsistency Rate & 0.090 \\
\hline
\end{tabular}

General evaluation results of smart museum criteria are given in Table 6 . It has been determined that virtual reality applications $(0.262)$ are the most effective in the selection of smart museums. In second place is interactive exhibition (0.111). Easy Access in Digital Vehicles criterion ranks third with its value $(0.079)$. It is seen that the least effective criterion in the selection of smart museums is used devices (0.046).

\begin{tabular}{|c|c|c|c|c|c|}
\hline \multirow{2}{*}{\multicolumn{4}{|c|}{$\begin{array}{l}\text { Comparisons wrt "Müze Seçimi" node in "Kriterler" cluster } \\
\text { 2. Sanal Gerçeklik is } 5 \text { times more important than } 1 \text {. Dijital Ulaşım }\end{array}$}} & \multicolumn{2}{|c|}{ Inconsistency: 0.09003} \\
\hline & & & & 1. Dijita & 0.13639 \\
\hline Inconsistency & 2. Sanal & 3. Interak & 4. Kullanı & 2. Sanal & 0.55580 \\
\hline 1. Dijital & $\uparrow 5$ & $\uparrow 3.0000$ & $\leftarrow 5$ & 3. İntera & 0.25891 \\
\hline 2. Sanal & & $\leftarrow 3$ & $\leftarrow 7$ & 4. Kullan & 0.04890 \\
\hline 3. Interak & & & $\leftarrow 5$ & & \\
\hline
\end{tabular}

Figure 9. Comparison Matrix of Smart Museum Criteria

Figure 9 contains the result of comparing the smart museum criteria with each other. According to the direction of the arrows, it is seen that Virtual reality criterion is more dominant than all other criteria. It is seen that interactive exhibition criterion is more dominant than the criterion of easy access in digital vehicles and used devices. It is seen that easy access in digital vehicles criterion is more dominant than only used devices criterion.

\section{Conclusion}

With the widespread use of the Internet, online museums, which are the website application used in museums, are also known as virtual museums. In online museums, the catalogs of the works, as well as information about the image and the work are included. The best example of these museums is the Sakip Sabanc1 Museum. It is important to reach visitors quickly in contemporary museology understanding. For this reason, museums are rapidly on the way to becoming spaceless and timeless. In the new understanding of museology, museums are constantly being renewed and have to keep up with the era by developing. While doing this, it has to take into account the interests, desires and skills of the new generation visitor mass. Display environments animated with touch screens, smart technologies, remote access technologies, virtual reality, augmented reality will increase the interest in museums and museum visits (Erbay, 2017, p. 265). Smart museum applications serve from one end of the world to the other in the form of an online museum, virtual museum, digital museum and e-museum. In this way, inaccessible museums can be visited by eliminating the disadvantages such as distance, cost and time restrictions. 
Face-to-face interviews in the study could not be conducted due to the Covid-19 pandemic. The data on museums were obtained as a result of phone calls and internet researches. The data about museums were obtained from the website of the reo-tek company, which produces interactive exhibition units for museums. In addition, 7 museums were selected by benefiting from studies on digitalization in museums in the literature. This is the limitation of the study.

In the research, 7 museums, namely Alanya Archeology Museum, Çorum Archeology Museum, Ankara Anatolian Civilizations Museum, Burdur Archeology Museum, Antalya Museum, Ankara State Painting and Sculpture Museum and Zeugma Museum, which have made attempts for the digitalization process, were compared according to smart museum criteria. As a result of the literature review, it is seen that many factors affect the smart museum selection. In the study, it was determined that the most important factor affecting the smart museum selection was firstly virtual reality applications. Afterwards, it is seen that the criteria of Interactive exhibition, easy access in digital tools and devices used are respectively. The ranking of smart museum selection is; Ankara Anatolian Civilizations Museum, Zeugma Museum, Çorum Archeology Museum, Antalya Museum, Ankara State Painting and Sculpture Museum, Burdur Archeology Museum, Alanya Archeology Museum.

Physical structures are affected by natural and man-made disasters together with their contents. Fire, earthquake, war, looting, terrorist incidents, which are always a great risk, cause the destruction of world heritage or works of art. Although smart museum applications are not a solution to such events, they can be used to protect and archive world heritage. In future studies, the motivations of tourists to visit smart museums can be examined. Smart museum activities can also be examined in museums belonging to the private sector.

\section{Ethical Declaration}

In the writing process of the study titled "Selection of Smart Museums According to Multi-Criteria DecisionMaking Technique: AHP Method", there were followed the scientific, ethical and the citation rules; was not made any falsification on the collected data and this study was not sent to any other academic media for evaluation. Since the data set is used in this article, ethics committee approval is not required.

\section{References}

Bayraktar, E., \& Kaleli, F. (2007). Sanal gerçeklik ve uygulama alanları, akademik bilişim'07 - IX. Akademik Bilişim Konferansı Bildirileri, 31 Ocak - 2 Şubat 2007 Dumlupınar Üniversitesi, Kütahya.

Baştanlar Y., Altıngövde, İ. S., Aksay A., Alav O., Çavus Ö.,Yardımcı Y.,Ulusoy Ö., Güdükbay U., Çetin E., Bozdağ1 Akar G., \& Aksoy S., (2006). E-Müze: müzeler için web-tabanlı gezi ve bilgi sistemi, IEEE SIU (14th National Signal Processing and Applications Conference), Antalya,Turkey.

Bilici, F. (2015). Pazarlamada artırlmıs gerçeklik ve karekod teknolojileri: tüketicilerin arturlmış gerçeklik teknoloji algulamalar üzerine bir alan araştırması (Yüksek Lisans Tezi). Uludağ Üniversitesi Sosyal Bilimler Enstitüsü, Bursa.

Bostanc1, M. (2019). Dijital müzecilik ve interaktif iletişim: SFMOMA ve MORİ dijital sanat müzesi örneklemleri. UNIMUSEUM, 2(2), 34-39.

Boyacı, M. (2019). Bellek tapınaklarından kitle iletişim araçları olarak müzeye dönüşümün izinde müze sorunsalına bak1ş. Sanat Dergisi, 34, 105-113.

Boyraz, B. (2013). Müze teknolojileri ve sergileme farkliliklar1. Akademik Bakış Dergisi, 39, 1-14.

Demirezen, B. (2019). Artırılmış gerçeklik ve sanal gerçeklik teknolojisinin turizm sektöründe kullanılabilirliği üzerine bir literatür taraması. Uluslararası Global, Turiz̨m Araştırmalar Dergisi (IJGTR), 3(1), 1-26.

Digital Museum, from; https://www.reo-tek.com/hakkimizda, Retrived 10.08.2020

Ekiz, M., Yerlikaya, M., \& Kaya, S. E. (2018). Görsel kültür eğitimi bağlamında yeni müze algisı ve sergileme farkl11ıkları, International Learning Teaching and Educational Research Congress, 6-8 Eylül, Amasya

Erbay, F. (2015). Müze gezmek insanın varoluşuna anlam yükleyen kişisel bir ihtiyaçtır. Kültür ve Turiz̧m Dergisi Aylık Kültür ve Sanat Dergisi, Kasim Sayısi, Özel Matbaası, Ankara.

Erbay, M. (2017). Yeni nesil teknolojiler ile müzelerde eğitim. Milli Eğitim Dergisi, 46(214), 255-268.

Göral, R., \& Tengilimoğlu, E. (2018). AHP ile çok kriterli turizm sektörü performans sıralaması ve uluslararası destinasyonlara yönelik bir uygulama. Presented at the Innovation an Global Issues in Social Sciences .

Güven, S., \& Ersoy, U. (2016). Çağdaş müzecilik değerlendirmeler ve öneriler. from, http://cagdasmuzebilim.ankara.edu.tr/wpcontent/uploads/sites/384/2016/04/\%C3\%87a \%C4\%9Fda $\%$ C5 $\% 9$ F-M\%C3\%BCzecilik-E\%C4\%9Fitimi-Degerlendirme-ve-Politika-\%C3\%96nerileri., Retrived: 02.01.2020.

Holdgaard, N. (2011). The use of social media in the Danish museum landscape. In Trant \& D. Bearman (Eds.), Museums and the Web 2011: Proceedings. Toronto: Archives \& Museum Informatics.

https://www.turizmgunlugu.com/2020/12/18/kultur-ve-turizm-bakanligi-yeni-sanal-muzeler/, Retrived 28.12.2020. 
ICOM (2019). from https://icom.museum/en/news/icom-announces-the-alternative-museum-definition-that-willbe-subject-to-a-vote/, Retrived 10.01.2020.

Johnston, R. S. (2014). History in Your Hand: A case study of digital history and augmented reality using mound 72. (Master Thesis), Graduate School Southern Illinois University Edwardsville.

Kervankiran, İ., (2014). Dünyada değişen müze alg1sı ekseninde türkiye'deki müze turizmine bakış. Turkish Studies International Periodical For The Languages, Literature and History of Turkish or Turkic, 9(11), 345-369.

Keş, Y., \& Başer Akyürek, A. (2018). Teknoloji ile büyüyen yeni nesil için interaktif müzeler. Medeniyet Sanat - IMÜ Sanat, Tasarm ve Mimarlk Fakültesi Dergisi, 4(2), 95-110.

Kounavis, C. D., Kasimati, A. E., \& Zamani, E. D. (2012). Enhancing the tourism experience through mobile augmented reality: Challenges and prospects. International Journal of Engineering Business Management, 4(10), $1-6$.

Korzun, D., Varfolomeyev, A., Yalovitsyna, S., \& Volokhova, V. (2017). Semantic infrastructure of a smart museum: toward making cultural heritage knowledge usable and creatable by visitors and professionals. Pers Ubiquit Comput, 21, 345-354.

Korzun, D., Yalovitsyna, S., \& Volokhova, V. (2018). Smart services as cultural and historical heritage information assistance for museum visitors and personnel. Baltic Journal of Modern Computing, 6(4),418-433.

Köse, N. (2017). Dijital pazarlamadan fijital pazarlamaya gecise örnek olarak arturlmıs gerçelik ve sanal gerçeklik. uygulamalarmm pazarlama üzerindeki katkılarmm incelenmesi (Yüksek Lisans Tezi). İstanbul Aydın Üniversitesi Sosyal Bilimler Enstitüsü, İstanbul.

Madsen, J. B. (2016). Aspects of user experience in augmented reality. (Doctoral Dissertation Thesis. Aalborg Universitetsforlag. Faculty of Engineering and Science, Aalborg University. Access adress: https://doi.org/10.5278/vbn.phd.engsci.00111.

Mil, B., \& Dirican, C. (2018). Endüstri 4.0 teknolojileri ve turizme etkileri. Journal of Multidisciplinary Academic Tourism (JOMAT), 1(3), 1-9.

Nelson, T. (2016). Impact of virtual and augmented reality on theme parks (Master Thesis). Master of Digital Media, Ryerson University.

Okan, B. (2015). Günümüzde müzecilik anlayış1. Anadolu Üniversitesi Sanat \& Tasarm Dergisi, 9, 187-198.

Oruç, Z. (2016). Müzede yeni gerçeklik. The Turkish Online Journal of Design, Art and Communication - TOJDAC, 6(2), 273-290.

Osterlund, J., \& Lawrence, B. (2012). Virtual reality: avatars in human spaceflight training. Acta Astronautica, 71,139150.

Önder, G., \& Önder,E. (2014). Çok kriterli karar verme. İçinde Yıldırım, B.F. ve Önder, E, Cok Kriterli Karar Verme yöntemleri,(ss.21-64) Bursa: Dora Yayınlar1.

Önder, G., \& Önder, E. (2015). Analitik hiyerarşi süreci. Edt. Yıldırım, ve Önder, Çok Kriterli Karar Verme Yöntemleri, Ankara: Dora Yayıncilik.

Özgan, S. Y. (2012). Use of augmented reality technologies in cultural heritage sites; Virtu(re)al Yenikapı (Master Thesis). Istanbul Technical University Graduate School of Science Engineering and Technology, Istanbul.

Özgörmüş, E., Mutlu, Ö., \& Güner, H. (2005, Kasım). Bulanık. AHP ile personel sę̧imi. V. Ulusal Üretim Araştırmaları Sempozyumu, 12-19, İstanbul Ticaret Üniversitesi. İstanbul. Access adress: http://acikerisim.ticaret.edu.tr/xmlui/bitstream/handle/11467/773/M01016.pdf?sequence=1.

Palaz, H. \& Kovancı, A. (2008). Türk Deniz Kuvvetleri Denizaltılarının seçiminin AHP ile değerlendirilmesi. Havaculk ve Uzay Teknolojileri Dergisi, 3(3), 53-60.

Ruotsalo, T., Haav, K., Stoyanov, A., Roche, S., Fani, E., Deliai, R., Makela, E., Kauppinen, T. \& Hyvonen, E. (2013). Smart museum: a mobile recommender system for the web of data. Web Semant: Sci Serv Agents World Wide Web, 20, 50-67.

Saaty, T. L. (1970). How to make a decision: the analytic hierarchy process. European Journal of Operational Research, 48, 9-26.

Saaty, T. L. (2008). Decision making with the analytic hierarchy process. International Journal of Services Sciences, 1(1), 8398.

Sarsılmaz, Y. (2010). Müzelerde teknoloji kullanımı. Anadolu Bil Meslek Yüksekokulu Dergisi, 20, 45-53.

Sertalp, E. (2017). Müzelerin tanıtım kitaplarında artırılmış gerçeklik (AG) teknolojisi kullanımı: Ankara Anadolu Medeniyetleri Müzesi kitabı örneği. Hacettepe Üniversitesi Güzel Sanatlar Fakültesi Sanat Yaz̨lar, 36(30), 107-120.

Sheridan, T. B. (2016). Recollections on presence beginnings, and some challenges for augmented and virtual reality. Presence: Teleoperators and Virtual Environments, 25(1),75-77.

Schweibenz, W. (2004). The development of virtual museums, ICOM News, no: 3.

Sucaklı, G. (2019). Turizmde modern müzecilik anlayısı ve artırlmıs gerçeklik uygulamalarmm müzelerde kullanım (Yüksek Lisans Tezi). Çanakkale Onsekiz Mart Üniversitesi Sosyal Bilimler Enstitüsü, Çanakkale.

Şardan, B. (2019). Modern müzecilikte kullanulan interaktif tasarm yöntemlerinin ziyaretçiler üzerindeki etkilerinin arastırlması (Yüksek Lisans Tezi). Mimar Sinan Güzel Sanatlar Üniversitesi Fen Bilimleri Enstitüsü, İstanbul.

Turan, G. (2014). Çok kriterli karar verme. İçinde B. F. Yıldırım ve E. Önder (Edt). Çok keriterli karar verme yöntemleri (ss. 15-20). Bursa: Dora Basım-Yayın Dağıtım.

Vaz, R. I. F., Fernandes, P. O., \& Veiga, A. C. R. (2018). Interactive technologies in museums: how digital Installations and media are enhancing the visitors' experience. In J. M. F. Rodrigues, C. M. Q. Ramos, P. J. S. 
Cardoso \& C. Henriques (eds.), Handbook of research on technological developments for cultural heritage and e-tourism applications (pp. 30-53). Hershey PA: IGI Global.

Yagol, P. (2018). Improving the user knowledge and user experience by using angmented reality in a smart city context (Master Thesis). Degree of Master of Science in Geospatial Technologies.

Yücel, D. (2012). Yeni medya sanatı ve yeni müze. İstanbul: İstanbul Kültür Üniversitesi.

\section{TÜRKÇE GENİ̧̧ ÖZET}

Kültürel, sanatsal, bilimsel ve tarihi özelliği ve önemi olan birçok eser, yapıt ve objeyi toplayan, koruyan, yorumlayan, sürekli ya da geçici sergilerle halkın hizmetine sunan müzeler turizmin önemli bir çekim unsuru ve alanlarıdır. Ayrıca müzeler, günümüzde ülkelerin gelir getiren kurumları arasında yer alması nedeniyle turizm olgusunun da merkezinde yer almaktadır. Bu sebeple müzelere olan ilginin artır1lması ve müzelerin bir çekim merkezi olarak daha fazla ziyaretçi çekebilmesi ve turizm sektörünün rekabetçi gücünün arttırılmasına sağladığı katkılar nedeniyle üzerinde durulması gereken kurumlardır. Bilgi teknolojileri ve internetin hayatımıza girmesi ile birlikte kültürel mirasin sergilendiği müzelerin de bu gelişmelere ayak uydurması ve elektronik ortama taşınması son derece önemlidir. Bilgi ve iletişim teknolojilerindeki gelişmelerin müzelerde uygulanması ve kullanılması bu mekânlara olan ilginin artmasına katkı sağlayacaktır.

İnteraktif müzecilik çalışmaları ile müze içinde simülatörler, kulaklıklar, sanal gerçeklik uygulamaları, kiosk, üç boyutlu yazıcılar, dokunmatik sistemler, bilgisayar odaları gibi teknolojik uygulamalarla daha fazla ziyaretçiye ulaşılmaya çalışılmaktadır (Mil ve Dirican, 2018, s. 6). Bu sebeple çalışmada müzelerdeki teknolojik uygulamalar çok kriterli karar verme yöntemiyle ele alınmışır. Müzelerde kullanılan teknoloji uygulamalarından sanal gerçeklik, interaktif sergileme, dijital araçlarda kolay ulaşım ve kullanılan cihazlara akıllı müze kriterleri olarak değerlendirilmiştir. Araştırma alanı olarak seçilen müzeler yukarıdaki kriterlere göre çok kriterli karar verme yöntemine göre incelenmiştir.

Çalışma alanı olarak, Alanya Arkeoloji Müzesi, Çorum Arkeoloji Müzesi, Ankara Anadolu Medeniyetleri Müzesi, Burdur Arkeoloji Müzesi, Antalya Müzesi, Ankara Devlet Resim ve Heykel Müzesi ve Zeugma Müzesi tespit edilmiştir.

Araştırmada ilk olarak turizmde dijitalleşme, dijital müze, akı1lı müze konuları araştırılarak akıllı müzeler için kriterler oluşturulmuştur. Elde edilen veriler incelendiğinde akıllı müze seçiminde birden fazla unsurun etkili olduğu tespit edilmiştir. Bu unsurlar şu şekildedir;

- Dijital Araçlarda Kolay Ulaşım Kriteri: Nerede, görsel bilgi, eser bilgisi, sanal tur bilgisi, interaktif alt yap bilgisi.

- Sanal Gezi Kriteri: Uygulama kolaylığı, gezi alanı yoğunluğu, 3D fotoğraf çokluğu, 3D bilgi çokluğu, dış mekân gösterimi, 3D gözlük.

- İnteraktif Sergileme Kriteri: AG uygulaması, dokunmatik ekran, bilgi, sesli rehber, diğer.

- Kullanılan Cihazlar Kriteri: Sesli rehber, yer-yön bilgilendirme, bilgilendirme panoları, kioks yoğunluğudur.

Tablo 1. AHP Tekniğine Göre Akıllh Müze Seçimleri

\begin{tabular}{lc}
\hline Müzeler & Puan \\
\hline Alanya Arkeoloji Müzesi & 0,006 \\
Çorum Arkeoloji Müzesi & 0,045 \\
Ankara Anadolu Medeniyetleri Müzesi & 0,085 \\
Burdur Arkeoloji Müzesi & 0,013 \\
Antalya Müzesi & 0,022 \\
Ankara Devlet Resim ve Heykel Müzesi & 0,017 \\
Zeugma Müzesi & 0,060 \\
\hline
\end{tabular}

Araştırma kapsamında yer alan müzeler için çok kriterli karar verme tekniğine göre akıllı müze kriterlerinin hangi müzede daha fazla olduğu gösterilmektedir (Tablo 1). Akıllı müze unsurları en fazla Ankara Anadolu Medeniyetleri Müzesi $(0,085)$ ile Zeugma Müzesi $(0,060)$ olduğu görülmektedir. Daha sonra sirasıyla Çorum Arkeoloji Müzesi $(0,045)$, Antalya Müzesi $(0,022)$, Ankara Devlet Resim ve Heykel Müzesi (0,017), Burdur Arkeoloji Müzesi $(0,013)$ ve Alanya Arkeoloji Müzesi $(0,006)$ olarak siralanmaktadir. 
Tablo 2. AHP Tekniğine Göre Akıll Müze Kriterlerinin Seçimleri

\begin{tabular}{ll}
\hline Kriterler & Puan \\
\hline Dijital Araçlarda Kolay Ulaşım & 0,079 \\
Sanal Gerçeklik Uygulamaları & 0,262 \\
İteraktif Sergileme & 0,111 \\
Kullanılan Cihazlar & 0,046 \\
Tutarsılık Oranı & 0,090 \\
\hline
\end{tabular}

Akıllı müze kriterleri genel değerlendirme sonuçları Tablo 2'da verilmektedir. Akıllı müze seçiminde, sanal gerçeklik uygulamalarının $(0,262)$ en etkili olduğu tespit edilmiştir. İkinci sırada ise interaktif sergileme $(0,111)$ yer almaktadır. Dijital Araçlarda Kolay Ulaşım kriteri aldığ1 değer ile $(0,079)$ üçüncü sıradadır. Akıllı müze seçiminde en az etkisi bulunan kriterin kullanılan cihazlar $(0,046)$ olduğu görülmektedir.

\begin{tabular}{|c|c|c|c|c|c|}
\hline Comparison & wrt "Mü & eçimi" node ir & "Kriterle & & \\
\hline & & & & 1. Dijita & 0.13639 \\
\hline Inconsistency & $\begin{array}{l}\text { 2. Sanal } \\
\sim\end{array}$ & 3. Interak & 4. Kullanı & 2. Sanal - & 0.55580 \\
\hline 1. Dijital & \begin{tabular}{|l|l|}
$\uparrow$ & 5
\end{tabular} & \begin{tabular}{l|l}
$\uparrow$ & 3.0000
\end{tabular} & $\leftarrow 5$ & 3. İntera - & 0.25891 \\
\hline 2. Sanal & & $\leftarrow 3$ & $\leftarrow 7$ & 4. Kullan & 0.04890 \\
\hline 3. Interak & & & $\leftarrow 5$ & & \\
\hline
\end{tabular}

Şekil 1. Akıllı Müz̨e Kriterlerinin Karşılaştırma Matrisi

Şekil 1'de akıllı müze kriterlerinin birbirleri ile karşılaştırma sonucu yer almaktadır. Okların yönüne göre Sanal gerçeklik kriterinin diğer bütün kriterlere göre daha baskın geldiği görülmektedir. İnteraktif sergileme kriterinin ise, dijital araçlarda kolay ulaşım ve kullanılan cihazlar kriterlerine göre daha baskın olduğu görülmektedir. Dijital araçlarda kolay ulaşım kriterinin sadece kullanılan cihazlar kriterlerine göre daha baskın olduğu görülmektedir

İnternetin yaygın kullanılmaya başlaması ile birlikte müzelerde kullanılan web sitesi uygulaması olan online müzeler, sanal müzeler olarak da bilinmektedir. Online müzelerde eserlerin katalogları ile birlikte görüntüsü ve eser hakkında bilgilerde yer almaktadır. Bu müzelere en güzel örnek Sakıp Sabancı müzesidir. Çağdaş müzecilik anlayışında ziyaretçilere hızla ulaşabilmek önemlidir. Bu sebeple müzeler hızla mekânsız ve zamansız olma yolunda ilerlemektedir. Yeni müzecilik anlayışında müzeler sürekli yenilenmekte ve gelişerek çă̆a ayak uydurmak zorunda kalmaktadır. Bunu gerçekleştirirken de yeni nesil ziyaretçi kitlesinin ilgi, istek ve becerilerini dikkate almak durumundadır. Dokunmatik ekranlarla canlandırılmış sergi ortamları, akıllı teknolojiler, uzaktan erişimli teknolojiler, sanal gerçeklik, arttırılmış gerçeklik müzelere olan ilgisi ve ziyaretini arttıracaktır (Erbay, 2017, s. 265). Akıllı müze uygulamaları online müze, sanal müze, dijital müze ve e-müze şeklinde dünyanın bir ucundan öbür ucuna hizmet vermektedir. Bu sayede uzaklık, maliyet ve zaman kısıtlaması gibi olumsuzlukları ortadan kaldırarak, mümkün olmayan müze ziyaretleri gerçekleştirilmektedir.

Araştırmada dijitalleşme sürecine yönelik girişimlerde bulunan Alanya Arkeoloji Müzesi, Çorum Arkeoloji Müzesi, Ankara Anadolu Medeniyetleri Müzesi, Burdur Arkeoloji Müzesi, Antalya Müzesi, Ankara Devlet Resim ve Heykel Müzesi ve Zeugma Müzesin olmak üzere 7 müze ak1llı müze kriterlerine göre karşılaştırılmıştır. Literatür taraması sonucunda, akıllı müze seçimini birçok faktörün etkilediği görülmektedir. Çalışmada akıllı müze seçimini etkileyen en önemli faktörün ilk olarak sanal gerçeklik uygulamalarından oluştuğu tespit edilmiştir. Daha sonra sırasıyla, İnteraktif sergileme, dijital araçlarda kolay ulaşım ve kullanılan cihazlar kriterlerinin geldiği görülmektedir. Akıllı müze seçimin sıralaması ise; Ankara Anadolu Medeniyetleri Müzesi, Zeugma Müzesi, Çorum Arkeoloji Müzesi, Antalya Müzesi, Ankara Devlet Resim ve Heykel Müzesi, Burdur Arkeoloji Müzesi, Alanya Arkeoloji Müzesinin şekildedir.

Doğal ve insan kaynaklı felaketlerden fiziki yapılar içindekilerle birlikte etkilenmektedir. Her zaman büyük bir risk olan yang1n, deprem, savaş, yağma, terör olayları dünya mirası ya da sanat eserlerinin yok olmasına sebep olmaktadır. Akıllı müze uygulamaları bu tür olaylara çözüm olmasa da dünya mirasını korumak ve arşivlemek adına kullanılabilmektedir. Bundan sonraki çalışmalarda turistlerin akıllı müzeleri ziyaret etme motivasyonları incelenebilir. Özel sektöre ait müzelerin de akıllı müze faaliyetleri incelenebilir. Müzelerde teknoloji kullanımının yaygınlaşması ile teknolojiye ilgi duyan kitlelerin dikkatini çekme ve 
müzelere olan ilginin ve ziyaretçi sayılarının artması hedeflenmektedir. Müzelerin teknolojik gelişmelere ayak uydurması, çağdaş ve profesyonel düzeyde etkinliğini arttırması son derece önemlidir. 